\title{
Germany may back military satellite project
}

Paris. The prospect of an independent European military satellite observation system moved a step nearer last week with reports that Germany is poised to back military space endeavours for the first time with a programme whose cost is estimated at between DM2 billion and DM10 billion (US\$1.3-\$6.69 billion) over the next decade. The United Kingdom is also said to be prepared to support a European programme.

Until now, France has led European efforts in military space. Its military space budget, the fastest growing such budget in the world, has soared from FFr697 million (US\$136 million) in 1987 to more than FFr4 billion this year. France already has a FFr9.23-billion Syracuse military communications payload aboard France Telecom's Telecom-2 satellite. Early next year it will launch its first high-resolution spy satellite, the FFr8-billion Helios-1 satellite.

Edouard Balladur, the French prime minister, recently reaffirmed that military space was a national priority. Indeed, the ministry of defence was last year given shared responsibility for the French space agency CNES. This institutionalized already strong links - both share the same industrial base, for example, while Helios-1 uses the platform developed by CNES for the SPOT-4 Earth observation satellite.

French enthusiasm for military observation satellites has a relatively simple explanation. France has nuclear weapons, and one of the functions of Helios is to act as a targeting system. Although the United Kingdom, Europe's only other nuclear power, has similar needs, it has so far relied on its close relationship with the United States for access to satellite data.

Until now, Germany has (like Britain) turned down invitations to join France's military efforts in space. One reason is that Helios-1 can operate only in clear skies, whereas Germany's security interests generally lie beneath cloudy skies, for example in Eastern Europe.

Germany's shift in position has been prompted partly by the decision of its constitutional court to authorize the operation of German peacekeeping forces outside the area of the North Atlantic Treaty Organization (NATO), as it needs an observation capacity to support such forces. On the industrial front, Germany is keen to support its sizeable satellite industry, while technologically the infrared capacity of Helios-2 - scheduled for launch in 2002 - allows it to see through clouds.

Germany's shift also coincides with a growing interest in the Western European Union (WEU), Europe's joint security organization, in establishing a satellite spying capacity independent of the United States. In 1991, WEU committed ECU38.25 million over three years for the construction of a WEU satellite ground station at Torrejon, near Madrid in Spain, to verify arms agreements and to monitor both security crises and environmental changes.

At present, the centre's main activity is the processing of images - for example from Bosnia - obtained from the SPOT series of satellites and other commercial suppliers. But it will soon handle classified images from Helios- 1 and become a 'mini Central Intelligence Agency' (CIA) for processing satellite images.

The centre has given European countries joint capabilities they could not have developed separately and access to images that the United States "would never have given

\section{ESA agrees to extra year for ERS-1}

Paris. The European Space Agency (ESA) has agreed to extend the operation of its remote-sensing satellite ERS-1 to the end of 1995 instead of shutting it down at the end of this year. The decision follows protests from scientists that shutting down ERS-1 in December would throw away an opportunity to carry out unique research, at little cost, using both satellites.

Researchers had argued that flying ERS1 and ERS-2 - which is scheduled for launch in January next year - 'in tandem' would, for example, allow interferometric studies to be carried out on large swathes of the globe, including all of Antarctica (see Nature 370, 317; 1994).

ESA officials say that the agency has agreed to spend another ECU2 million to keep ERS-1 operational for another year in a 'safe orbit'. But member countries are still divided over whether to pay a further ECU6 million for the operational costs of a dedicated 'tandem' mission.

ESA says this sum could easily be found by taking funds from ERS- 2 and reducing its lifetime by a few weeks, although some political problems remain because the countries paying for ERS-1 are not identical to those paying for ERS-2

But, despite caution from several ESA members over the financial aspects, the German space agency DARA says that the "scientific and technological case [for a tandem mission] has now been made", and is optimistic that the extra money will be found.

ESA officials also point out that even without extra funding for the operational costs of a dedicated tandem mission, the new lease of life given to ERS-1 means that it will in fact now function in tandem with ERS-2 all next year.

D.B.

\section{IMAGE UNAVAILABLE FOR COPYRIGHT REASONS}

\section{France's Helios- 1 satellite is winning more European supporters}

them", says Stephane Chenard of the space consultancy Euroconsult in Paris.

France also needs European collaboration to afford its costly military programmes. It has paid 80 per cent of the costs of Helios1 (Italy contributes 14 per cent and Spain 6 per cent) but cannot afford the FFr10-billion Helios-2 alone, much less its planned FFrl 1billion Osiris radar satellite, scheduled for launch in 2004.

Moreover, Spain last week pulled out of Helios- 2 for budgetary reasons, leaving the French with a gap in funding, while Italy, which is reviewing its defence policy, has yet to decide whether to participate.

But this gap now seems likely to be filled by Germany, which is expected to announce its participation in Helios-2 at a FrancoGerman summit in November.

Officials from the relevant ministries in Germany are refusing to comment publicly on their plans. But newspaper reports suggest that the participation is linked to an agreement that Germany should lead the Osiris programme, in which it will make a financial investment of up to 50 per cent.

The possible rapprochement between German and French efforts in military space is also indicated by a proposed merger between the satellite and missile divisions of Aerospatiale of Paris and Deutsche Aerospace, which will probably lead to the creation of a joint subsidiary in Munich.

As so often in European affairs, the joker in the pack is the United Kingdom, which has privileged access to CIA satellite data. But Britain apparently now recognizes that it shares security interests with France and seems ready to invest in Helios- 2 .

In principle, Britain does not seem opposed to a European military space effort. The industrial advantages are obvious, while military bodies, faced with strong budget pressures, are searching for a pragmatic, rather than a political solution, say observers. Increasingly, Europe wants its own missile warning system in order to reduce dependency on US goodwill in sharing data, they say.

Declan Butler 